\title{
電圧一時間特性からみた污損沿面放電特性 の検討
}

$\begin{array}{lllll}\text { 横浜国立大学 } & \text { 西 } \text { 村 誠 } & \text { 介 } \\ \text { 東洋大学 } & \text { 中 } & \text { 島 好 } & \text { 忠 }\end{array}$

\section{1. まえがき}

電力系統の高電生化と高信頼性の要求加ら，系統絶 縁の耐污損刘策は重大な問題として国内的にも国際的 にも各種委買会で精力的な研究驾進められている。酎 污損性能良好ながいしの設計，污損試験法の罗当捗， 合理的な保导方法を娭討するうえで，污損沿面放電の 本性を的確にはあくしておくことは有効かつ必要であ Bo

これまでに污損沿面放電の機檏についてはいくつか の研究があり，大きく分けて次の二つとなるう。一つ は, 50\%フラッシオ一八゙值程度の比較的低い電代印 加時にみられるようなフラッシオ一バまでに数回の発 生・消隇を繰り返す局部アークの進展機構の説明で ある。著者の一人中島 ${ }^{(2)}$ は污損液皮膜温度の上昇化着 目し，沸点に達したときの乫発変化としてアーク伸長 在考えた。富永 ${ }^{(2)}$, 瀨田氏 ${ }^{(3)}$ は局部アーク先端の皮膜 通路部分はシュール熱により $100^{\circ} \mathrm{C}$ 近くになる上気泡

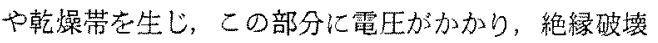
して周部アークが伸ひるといういわゆる通路の熱变形 先導の考え方により計算值と夷験値との対応をよって いる。むう一つはインパルス電左のような極めて高電 区を印加した場合のもので，赤崎氏 ${ }^{(4)}$ は唀電体沿面に する Toepler 理諭の拹張を試みている。Boylett 氏 ら (5)は，水溶液面に生ずる放電は筀気中金属電極間の 放電とは異なった特性をもつととを示唆し，高電生回

Study of the Leakage Discharge Mechanisms on Polluted Sur. faces Based on the $V-t$ Characteristics. By S. NISHIMURA, Member (Department of Electrical Engineering, Yokohama National University) \& Y. NAKAJIMA, Member (Depart. ment of Engineering, ToyO University).

西村誠介：正買，横浜園立大学工学部電氮工学科

中品好忠：正抟，東洋大学工学部

昭 50-2
加時にはリヒテンベルク図と類似の6のになると報告 している。しかし印加電圧を低い值から潮次高めてゅ くと局部アークの進源速度は加速され，乙れに反し通 路の熱変形の程度が整減し，さらに印加電王の極性に よってアーク進展現象に善があるこ上も実駼的に知ら れており，上述各氏の检討範囲の間にあう一つの領域 があること若えられる。

本諭文では，塩水皮膜上に形成されるアークスポッ ト (アーク電極点) には不明な点が多いのでその解明 の一端として，印加電压を低い値加ら十分な過雪王に まで, 変化させたときの污損沿面放電進展機構の変僄 を幅広くはすくすることを目指して実験検討を行なっ to

なお，ここにいうアーク進展の現象は，污挰がいし のフラッシオーバのさい, 執操帯を橋絡した局部アー クが，印加電压の大半が加わっている湿潤带上を伸び る現象と本質的に対応しており，污損フラッシオーバ 過积中で最も重要な意味をもつものである。

\section{2. 実験の方法}

塭水皮膜上にアークを発生・進屡させるため，第1 四の上うな形状に裁断した新閪紙に所定浱度の食塩水

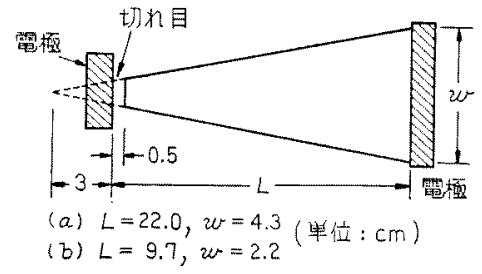

第 1 図三角形漏孔通路

Fig. 1. Narrow tapering strip of leakage path. 
（10０.1\%）苍浚させ，これを水平なガラス板上に の世金属電極老配して供試漏扎通路上した。漏机通路 を三角形（正しくは台形であるか，筆者らのこれまで の通称(1) 従がここでむ三角形通路上呼心ことにす る）とした主な理由心，アークの進屡方问走常に一

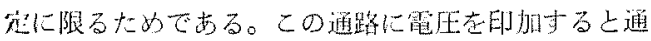
路上の頂点例霓極に近い上ころほど，膤机電流の密度 は大きく，したがって通路友膜に注入される電力密度 も大となり，局部アークは必ず頂点側電極のきわに発 生し，電力密股の小さい底辽側電柾のほう八向って進 剧する。すなわち，こてで三角形通路を用いることは あたかもコロナ放電の研究で同心円筒間げきや釗対平 板間げきが使用さ机るの上同じ理由である。また，通 路の頂点側の一端任睘 $5 \mathrm{~mm}$ の切れ目を設けたのは， 電極間に矩形波電圧を印加したとき，局部アークの進 层时間を電在印加からフラッシオーバまでの封間と一 致させるためである。もし，切机目䘮付けなけ机ば電 F:印扣後，電流密度が最大の頂点側電極きわの通路部 汃漏机電流の発熱作用で沸点仪達し，水分の蒸祧・飛 敬よにりここに細かい切机目ができるのを待って初め て局部アークが発生する。すなおち，電生的加加らフ ラッシオーバまでの間には局部アークの進展封間 $t_{d}$ に先だって，通路の一端に細加い切机目を生ずるま での時間 $t_{i}$ が含ま机ることとなり，両者を弁別する 作業少必要之なる。しかし，あらかじめ切机目老付け ておくと，電生印加と同時にこの部分に局部アークが 発生し上述の時間 $t_{i}$ t 0 とすることができ，ア一 ク進展時間 $t_{d}$ のみを容易に測定することが可能之な る。

試験回路は第2図に示したと扣りであららかじめ充 電したコンデンサにより試料通路の電極間矤形波電 压在㽖加して，通路上索進展しフラッシオーバにいた るアークの写真観察や $V-t$ 特性老調心，放電特性を 娭討する。なお，放電進展中に電源電圧が目だった減 露をしないよう電源コンデンサの容量を極力大きくす るよう心がけた（隇夜の程度は第 3 図のオシログラム 老参照)。

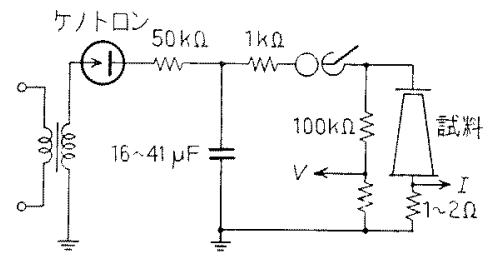

第 2 図実験回路

Fig. 2. Experimental circuit.
進展中のアークの梯相は陚料の横方向から回転力メ ラで流し写真として撮影し，乙れ之同時に印加電王， 放雪電流の波形をシンクロスコープで観察することと した。回転カメラは収光レンズ後方に置いた円周 28 $\mathrm{cm}$ の回転円筒に印画紙を巻き付け，数百〜数干 $\mathrm{rpm}$ の速度でモー吅駆動する仕組になっている。さらに放 電進展の透中で印加電圧を球間げきでさい断し，放電 を中止させたときの放電の経路，先端の㥞相を観るた めに，試料直上にシャッタ開放の暗雨力メラを設け静 止写真の撮影も行なった。

\section{3. 塩水皮膜上のアークの写真観察}

第 3 図(a)，(b) に三角形[第 1 図(a)]漏机通路上 を進展するアークの流し写真の一例を示す。以下説明 簡単化のため正極性電極加発生進展するアークを正

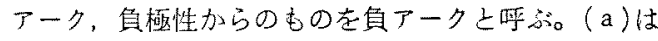
正アーク，（b)は負アークの進展状況て，同一印加電 圧值に対しては一般に正アークのほうが進展速度が大 きく,この写真ては約 4 倍となっている。また, 絓通路 上を進展する正アークでは陽光柱の中に輝度の強弱を 伴い，この程度は印加電任を低くするほど著しい。この 輝度の強弱は紙通路から発生する分解ガスの不均一さ によると見受けられ，さらに発展すると紙の然㜔につ ながるようである。負アークでは輝度の強弱は現わ机 にくく、アークスポット近くの通路部分に供給される エネルギー密度に極性差があることを示唆している。 (c)〜（f）は放電進展の途中で, 印加電圧をさい断し て放電の経路・先端の様相を観察したものの一例であ る。(c)，(d) K見ら机るように，常に正アークは先 端が先鋭，負アークはアーク柱が太く真直化進む傾向 があり，之机机正負了ークのスポットの形状や大き さに差異があるこ上を物語っている。過電压を印加し

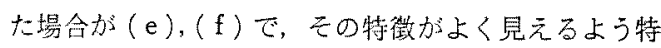
に平等幅通路を用いたが，正アークには多数の樹枝状 の分岥があり，負アークは通路いっばいに広がった中 から細く先鋭な先端が一本伸びているのが見ら机る。

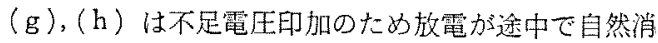
堿するときの状況を，三角形通路について流し写真上 して撮影したもので, 正アークは陽光柱の輝度が低く なった後にもアークスポットはなな找存しているが 負アークは逆にアークスポットから先に消減して抢り スポットが放電の維持に果す役割の違いを暗示してい る。

\section{4. 印加電圧-進展時間特性}

〈4.1〉 $\boldsymbol{V}-\boldsymbol{t}$ 特性 限られた電源電任のもとで不 

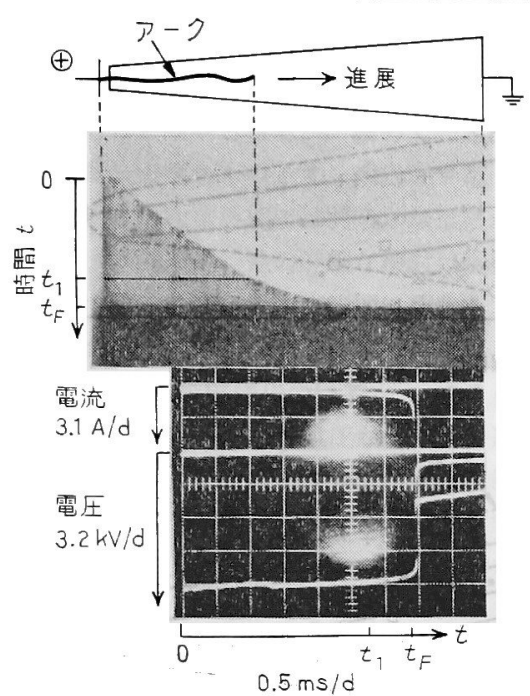

(a)

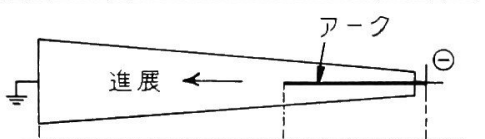

いずれも $3 \%$ 食塩水を新聞紙化含浸

第 3 図 アーク進展状況の写真

Fig. 3. Photographs of deveropments of discharge on polluted surface.

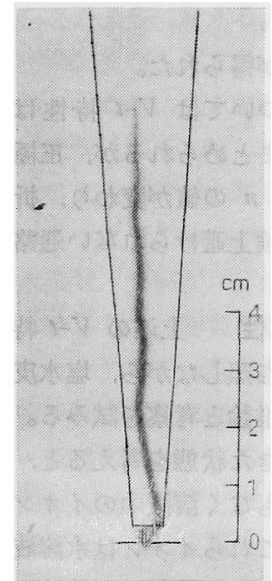

(c)

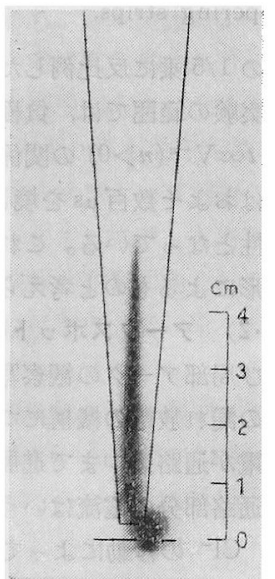

(d)

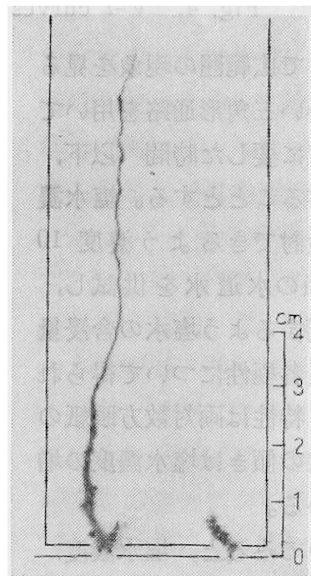

(e) (b)

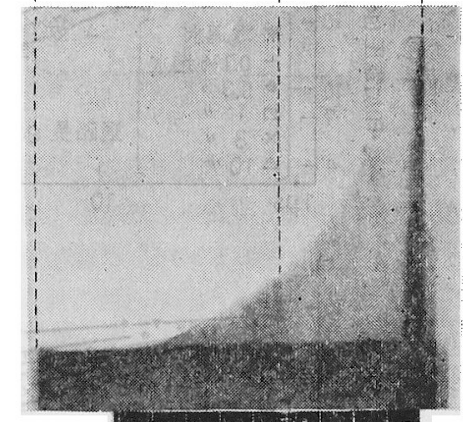

$3.1 \mathrm{~A} / \mathrm{d} \downarrow$

電圧 $3.2 \mathrm{kV} / \mathrm{d}$

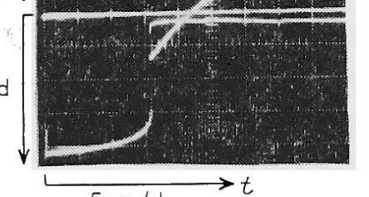

$5 \mathrm{~ms} / \mathrm{d} \longrightarrow t$

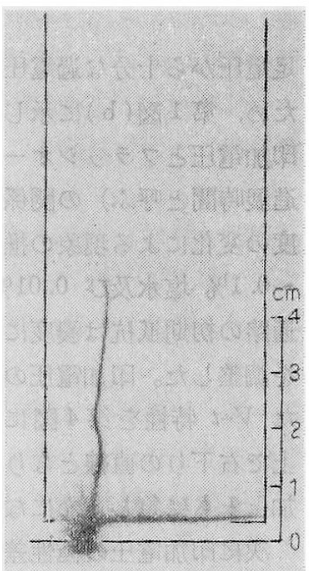

(f)

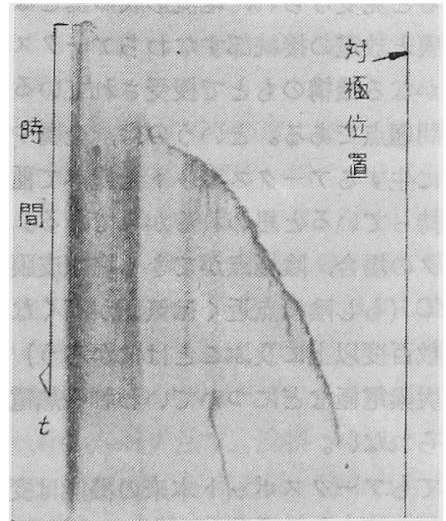

(g)

(c) 正アーク, 試料: 第 1 図(a), $15.2 \mathrm{kV}$ 矩形 波さい断, さい断時間 $2 \mathrm{~ms}, 12.5 \mathrm{kV}$ 囵加

(d) 負アーク, 武料: 第 1 四(a)，15.2kV矩形 波さい断,さい断時間 $4.6 \mathrm{~ms}, 12.5 \mathrm{kV}$ 印加

(e) 正アーク, $4 \mathrm{~cm}$ 平等幅通路, 長さ $15 \mathrm{~cm}$, 絵頭波過電圧さい断, さい断時の䉓圧 22.4 $\mathrm{kV}$ ，さい断時間 $1.6 \mathrm{~ms}$

(f) 負アーク, $4 \mathrm{~cm}$ 平等幅通路, 長さ $15 \mathrm{~cm}$, 䌊頭波過電圧さい断, 引いい断時の電圧 24.8 $\mathrm{kV}$ ，さい断時間 $2.0 \mathrm{~ms}$

（g）正アーク，自然消滅の様子, 試料及ご配置は 第 3 图 (a) と同し，10 kV 印加

(b) 負アーク, 自然消堿の棁子, 壾料及び配置は 第3 図(b)と同し，10kV 印加

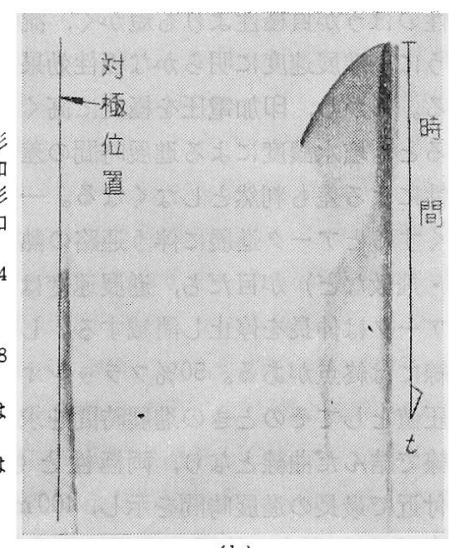

(h)

昭 50-2 


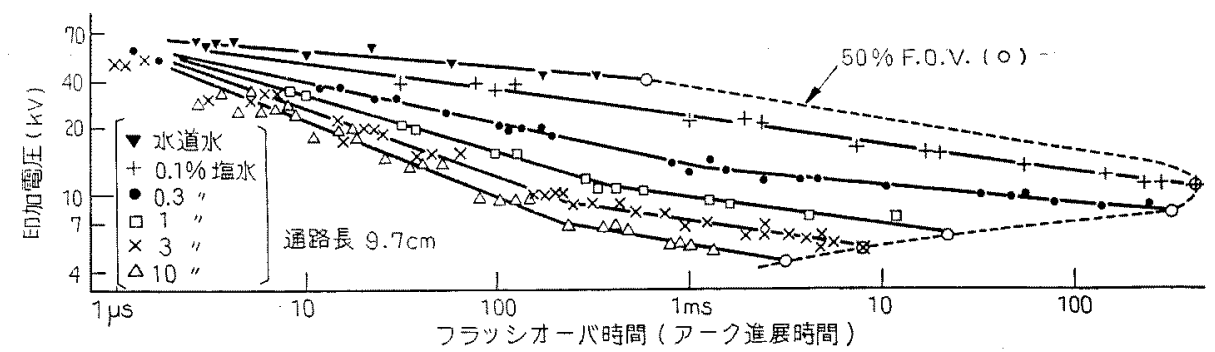

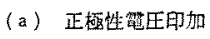

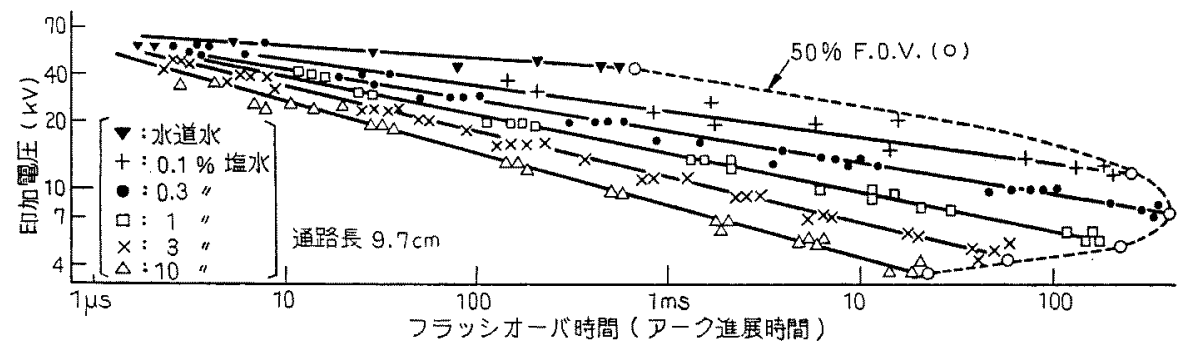

(b) 負粫性軍王印加

第 4 図四加電任上アーク進展時間の関係

Fig. 4. $V-t$ curves for tapering strips.

足電王から十分な過電王印加まで広範围の現象を見る ため，第 1 罒(b)に示した短加い三角形通路を用いて 畉加電压とフラッシオーバまでに要した時間（以下， 進展時間と呼引゙）の関系を調べるとととする。塩水濃 度の変化による現象の㨦移も㭘討できるよう濃度 10 $\sim 0.1 \%$ 塩水及ひ $0.01 \%$ 相当の水道水供試し， 通路の初期抵抗は濃度に反比例するよう塩水の含浸量 を調整した。印加電圧の正・負各極性について得られ た $V-t$ 特性を第 4 図に示吉。特性は両効数方眼紙の 上で右下りの直線となり，直線の傾きは壏水濃度の增 加とともに急しゅんになっている。

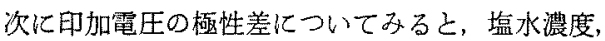
印加電生值を等しくしたときの進展時間は一般に正極 性のほうが真極性より李短汃く，流し写真です見たよ うに，進展速度に明らかな極性效果があるととがわか る。しかし，印加電生を極度に高く $(60 \mathrm{kV}$ 程度 $)$ す る上，塩水濃度による進展時間の差は小さくなり，極 性による差も判然としなくなる。一方，印加電生荧低 くするとアーク進展に伴う通路の熱变形（水分の蒸発 ・飛散など）が目だち，進展速度は低下し，ついには アークは伸長を停止し消隇する。したがって，V-t 曲 線には終点がある。50\%フラッシオーバ值を終点の電 圧值としてそのとさの進展時間を求力ると第 4 図中点 線で結んだ曲線となり，雨極性とも濃度 0.1 0.3\% 付近で最長の進展時間を示し， $400 \mathrm{~ms}$ にす達する。濃 度 $0.1 \%$ 以上の範囲では $50 \%$ フラッシオーバ值は
濃度の 1/5 乘に反比例しだ結果が得られた。

本実験の範用では，目極性については $V-t$ 特性は 大略 $t \propto \mathrm{V}^{-n}(n>0)$ の関係式にまとめられるが，正極 性ではおよそ数百 $\mu$ sを境として $n$ の值が変わり，折 線特性となっている。これは実験上避けられない通路 の変形による6の上考えられる。

〈4.2〉 アークスポットの特異性 上述の $V-t$ 特 性及び局部アークの観察写真を参照しながら，塩水皮 膜上の漏れ放電の機構について推論と考察を試みる。

放電が通路途中まで進展してきた状態を考えると， 残余通路部分の電流はいうまでもなく溶液中のイオン $\mathrm{Na}^{+}$，Cl- の移動によって求りこれらイオンは水溶液 中では一般に水和状態にある。他方放電部は過渡的な アーク放電に類すると見受けられ，電流形成の基とな る電子が，塩水皮膜と放電の接続部すなわちアークス ポットに执いていかなる機構のるとで授受されている 加を解明するとが問題点である。というのは，金属や 炭素などの導体上に生ずるアークスポットと比べて種 々異なった特性を持っていると思われるからである。 たとえば，正アークの場合，陰極点ができる塩水皮膜 はその沸点が $100^{\circ} \mathrm{C}$ （6し陰極点近くは気玨が高くな っているとしても数百度队上に及ふてとはなかろう） であるため，通常炭素電極などについていわれる熱電 子放出穖構は考えられない。

印加電圧を変えてもアークスポット本来の機能は変 わらないまでも，低電王目加時には屚れ通路の発熟. 
作用で水分の蒸発・水溶液の飛散あるいは塩水の電気

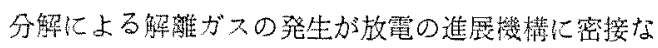

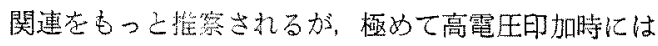
直接水溶液表面加らの1 屯可能となり放笔譏構には明ら加推移がるられる。

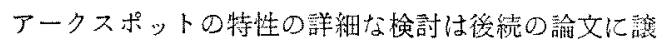
るとして、ここでは極力広籍国に現象を力バーするこ とに心がけ巨現的な検尌を行なう。

〈4.3〉放電の機搆について フラッシオーバ声

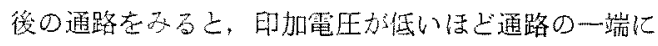

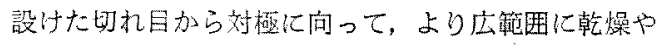
塩水飛散などの通路の熱变班が激しく温度上年む大き い。また，流し写真でみたよらにアークスポッ卜は水 蒸気ならびに新聞䋏からの分解がスの発生艺侀いなが ら進展する。さらに印加電王の極性の正具に加加ら ず淂光社は黄赤色呈し分光分析によると $\mathrm{Na} の D$

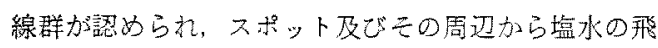
沫汃放霓の中八垒き迅まれていると見られる。

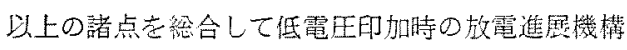

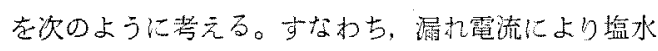
皮膜温度が上萃する。特に，㫣流線の集中が著しいス ポット直前は泩入される電力密度力゙大きいたか短時間 で皮膜は沸点に壦し，皮膜の内部加ら急激な蒸発・塩 水の飛散が行なかれあたか子液体フューズ燃断の上き のようにこの部分がアーク上なる。スポット周匀には 水蒸気，分解ガス，塩水の飛液が多墨にあり，これら の熱あるいは整突電離により放䨔に必要な電流が供給 されアアーク络進征し，フラッシオーバにいたる。撸 亚すれば皮膜に注入きれる熱エネルギーがアーク進展 ・維持に大きく帮与しているという意味でての分野を 熱的進展の機構上呼ふことができよう。極性による進 展速度の差は皮膜上に形成されるアークスポットの形 状の違い起因すると考えられる。写真観察では明ら かに，正アークは負アークに比へて先端が先鋭て， ス

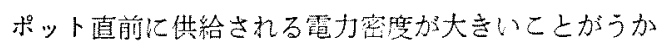
がこよう。

次に用加電左を数度に高く（約 $60 \mathrm{kV}$ ) した場合， 僬展時間は嚓水浀度，極性による差が判然としなくな る。これほど高電压てなくても，進展時間が短かく なればなるはど，通路上の一点に着目したときるこに 注入される熱エネルギーは減少し皮膜溶液の沸膦は考 え難くなる。すしての領域です低電圧印加の場合之同 様熱的機構が保たれているとして, 後述 $\langle 5.3\rangle$ 節の step-by-step 法で，皮膜への注入エネルギー一定，す

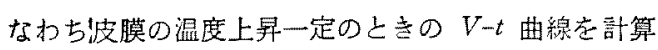
すると，大略一1/2 の㑯きとなる。しかるに奏験結果
は乙れより屯小さい傾さとなっでり，放電譏構が変 化していること走示唆している。アータスポット直前 は電流の集中に上り皮膜俻上に强霓界が生じている。 放電進㭚儿は熱エネルギーよりもむしるスポット周辺

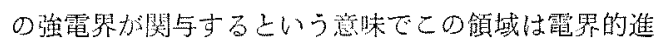
展機棈上名づける。

最後に，熱的領域之電罢的領域との中聞の領域につ

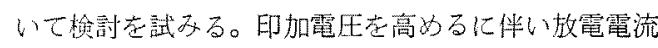
古增大し淮展㻋度は著しく加速される。しかしフラッ シオーバ後に見られる道路の偝变形の程度はかえって

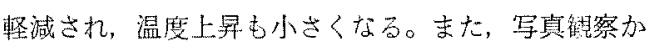
らは電压の増加につ扎放電先端が先鋭化し, スポット 直前の電界強度が增大するようすがうかが觉る。これ らの所見を総合する上，㽖加電圧上算に伴いスポット 直前の雪鱼強度が大となるにつれ，皮膜中の熱工ネル ギーによって放出される水蒸與や分解がスが少量でむ アークの維持・進祭に必要㠺電流を得るととができる ようになると推察される。アークスポット近くの放電

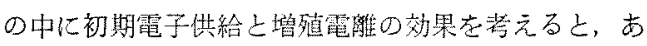
たかも水蒸気や分解ガス叒生の熱的現象は前者に，電 界强度の增大は㣪者に大きく関与して，その再者が相 補的な関係在むって放笔の進腿に作用しているという 印象を受ける。したがってこの領域のアーク進展機 棈老本諭文では熱電的上呼ふこととする。

以上 $V-t$ 特性を基して放電や通路の様相を観察し

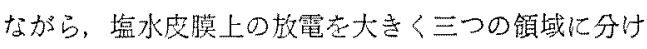

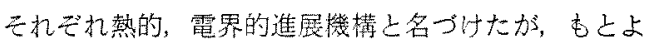
り各領域間に明磼な境界はない。

〈4.4〉50\% フラッシオーバ值について 第 4 図 にホした 50\%フラッシオーバ電王とそのときの進展 時間との関係について考える。この領域では放電進展 は熱的機構によっている。したがって，放電が持続進 展できる加否かは，通路の熱变廷心進み方いかんによ る。ここで放電現家のほうからアーク消減の条件老調 ベる目的で，第 1 図(a)の寸法の試料について, 放電 の流し马真上電流オシログラムから，アークが焦展を 停止し消隇する直前の電流值を求多，アークの長さと の関係走したものが第5图である。畞加電圧，極性 を変化して李結果は一本の四線となり，との電流值よ り小さくなるとアークが消減すること意味し，放電 の維持には臨界電流值が存在するよう見受けられる。 すなわち，残余通路の熱变形による抵抗值の増大のた め放電加消減するか，放電伸長に上り残余通路を短縮 して持続進展するかは臨界電流值しの関係で决まる。

さて，塩水濃度を大として通路の抵抗值を低くする 乞皮膜に注入される電力密度心著しく增大し通路の熱 


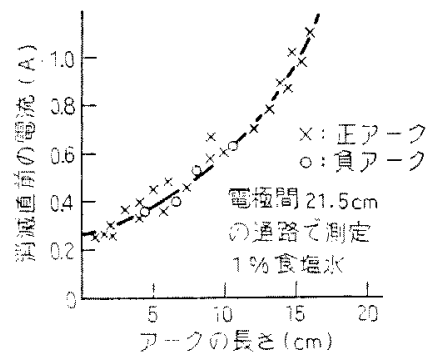

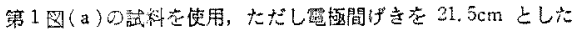

第 5 区 放電の臨界電流

Fig. 5. Critical current of discharge.

变形は促進され，第 4 図のように0.1\%から濃度が大

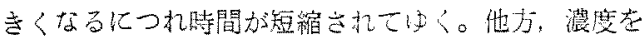
$0.1 \%$ より減少して屯 $50 \%$ フラッシオーバ値に対す る時間はやはり短加くなっているか，これは放電情構 の変邆による上考无引机る。濃度加 $0.1 \%$ 以下儿なる と $50 \%$ フラッシオーバ値付近の電生印加時でも陽光 柱の色は黄赤色加らしだいに青白味老び空気中のス

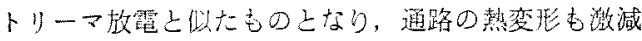
する。すなわち，濃度の低下とともに，放電進展機構 が熱的加電界的なもの人と推移して必く々解躯され る。

\section{5. 局部アーク進展速度の熱的検討}

〈5.1〉局部アークの速度分布放電の流し写真

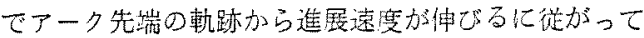
加速ざれている。用加笔圧が此较的低くフラッシオー バまでの時間が約 $1 \mathrm{~ms}$ 程度以上の揚合には, 流し写 真から通路上各点でのアーク進展速度を読み取ること ができる。しかしフラッシオーバまでの時間が短かく なると，流し写真の撮影部が短かくなり正確な测定が 困蜼となる。そこでアータ造展方向上直角に $1 \mathrm{~mm} \phi$

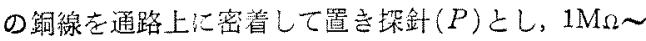
数百k几の高抵抗分圧器に接続する。アーク進展に伴 う $P$ の電位変化をンンクスコープで観察し， $P$ の 位置に了ークガ䜧するまでの時間を読み取る。進展す るアークスポット近くに治強電界加䈎中して叔り，ア

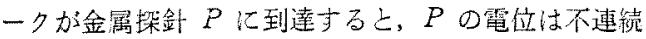
变化する。Pの㕸䈯を変えて，元の点までアークが進 展してくるに要する時間定求わたの方第6四である。

同一条件下です测定のたびに結果は加なりの籍阙汇 ばらつくが，ほぼ平均的に一本の曲線に回帰でき乞う である。確認の意味で流し写真加ら求めた結果と比较 するとばらっきの範国内で合致している(第6 6 図)。片 対数方眼紙上に画いたアークの長さ上進展時間の関保

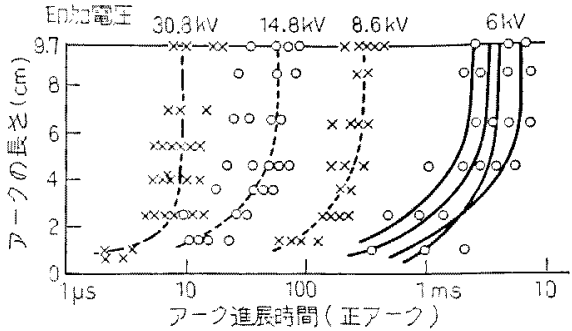

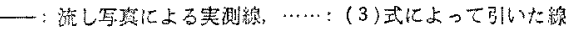

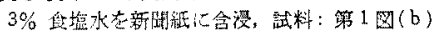

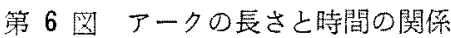

Fig. 6. Characteristics of are deveropment.

曲線は、印加電玨が買なっても極めて類似の形をして いる。特化塩水搌度 0.1 10\%，フラッシオーバ职間 が $10 \mu \mathrm{s}$ 以上の範思ではただ恃間的に平行移動したよ

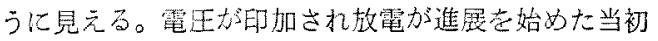
電流は小さく，アークスポット近くへ集中する麗界す 弱い。進展速度は湿人熱的進展機構を示す。アーク方 長ずるに從い先端の電界強度手增大し熱露的機構の㥞 相を带び，進展は加速さ机る。さらに伸びると短加く なった残余通路汇印加電㭱の大半が加和り電照的進展

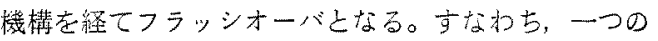
放電進展に伴っても放電の様相は熱的なむの加らしだ いに電界的なすのへ上变化している。しかし，フラッ シオーバまでの時間方 $10 \mu \mathrm{s}$ 以下となるような高電压 印加の場台には，第 6 図の特性幽線は先の場合に比べ ていくらか変形している。アーク汃通路一端の切れ目 から 1〜2cm 伸びるまでにフラッシオー，時間のほ とんごを費やし，残りの通路は瞬洔に電界的機構沙よ り進展することが見取られる。

〈5.2，通路の温度上昇とアークの進展臼加電 圧低くアークの進展兮熱的機構によっている場合を考 える。アークスボット直前の通路皮膜は波勝状龍にあ る。この部分の電流密度がいくらである汃はスポット の形汱が明解にされない限り算定できないしかし， ここからわずかに離机る上䉓流線は急に広がり通路福 一ぱいに及ルでいるで古万う。いま，電流線が通路幅 一将い広加った場所の皮膜温度加 $100^{\circ} \mathrm{C}$ 保ってい ると仮定劣。この場所加らスポットまでの部分は注 入されるエネルギールよって潜熱加供給され蒸発や塩

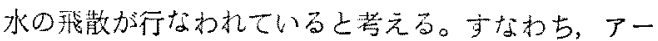
クスポットは皮膜温度が $100^{\circ} \mathrm{C}$ に上昇した場所のすぐ 近くにあり，この温度上㫒に先導されて進む。したが って, 这江皮脱温度が $100^{\circ} \mathrm{C}$ に上昇する場所の移動加 らアーク進展のようすがうかがえるとととなる。この 考え方成速して篚者の一人中島は，以前，アーク電 
王を零上して皮膜温度が $100^{\circ} \mathrm{C}$ になる場所の移動速度 $S$ を(1)式で表わしている。

$$
S=\frac{V^{2}}{2\left(E_{100}-E_{n}\right) \rho l_{0}\left(\ln l / l_{0}\right)^{2}}
$$

ことに， $V$ : 印加電王， $\rho$ : 塩水の固有抵抗

(温度によらず一定上する)， $E_{n}(=4.2 n$ joule/

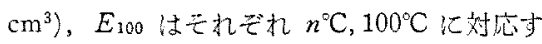

る皮膜のエネルギ一密度, $l_{0}$ : 三角形通路の

顶点から $E_{100}$ の場所志での距離, $l:$ 頂点か

ら測った通路の全長

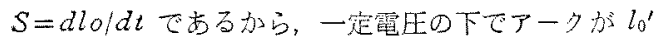

まで進晨するに要する時間は (1) 式加ら

$$
d t=2\left(E_{100}-E_{n}\right)\left(\rho / V^{2}\right) l_{0}\left(\ln l-\ln l_{0}\right)^{2} d l_{0}
$$

ここで

$$
\begin{gathered}
\int l_{0}\left(\ln l_{0}\right)^{m} d l_{0}=\left(l_{0}{ }^{2} / 2\right)\left(\ln l_{0}\right)^{m} \\
-(m / 2) \int l_{0}\left(\ln l_{0}\right)^{m-1} d l_{0}
\end{gathered}
$$

なる関禹式を利用して $(2)$ 式を棈分し， $l=12.7 \mathrm{~cm}$, $t=0$ で $l_{0}^{\prime}=3.5 \mathrm{~cm}$ 上すると，

$$
\begin{aligned}
t= & 2\left(E_{100}-E_{n}\right)\left(\rho / V^{2}\right)\left[\left\{\left(\ln l_{0}^{\prime}\right)^{2}\right.\right. \\
& \left.\left.-6.08\left(\ln l_{0}^{\prime}\right)+9.50\right\} l_{0}^{\prime 2} / 2-20.9\right\}
\end{aligned}
$$

となる。3\%塩水通路の正極性での $50 \%$ フラッシオー バ值 V=5kVについて上式からフラッシオーバ時間 を算出すると $\left(\rho=7 \Omega-\mathrm{cm}, l_{0}^{\prime}=12.7 \mathrm{~cm}, n=20^{\circ} \mathrm{C}, E_{20}\right.$ $=84$ joule $/ \mathrm{cm}^{3}, E_{100}=420$ joule $\left./ \mathrm{cm}^{3}\right), t \fallingdotseq 3 \mathrm{~ms}$ となり

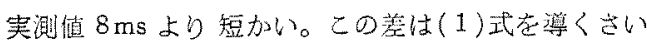
ルアーク電圧上熱損失在無視したことああるが，さら 行簡単のため塩水の固有抵抗を温度によらず一定とし て液体状態での最低值 $\left(100^{\circ} \mathrm{C}\right.$ 時の值) 朋いたとと が大きな原因之考えられる。瑷述の上うに 2 を温度よ ともに変化させ， step-by-step 法で算出した結果は，

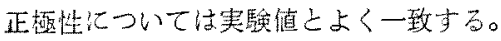

(3)式の計算値は実䂆值と此べて㭙間的なずれはあ るが，特性曲線の形杜非常によく似ていることが注目 される。つまり(3) 式の時間在適当行定数 $(k)$ 倍すれ ばそのまま，塩水1〜10\%でフラッシオーハ時間が 10 us 以上の場合の実験結果の平均的な回㷌此線として 用いることができる。第6图の曲線は彗はこのように して画いたものであるがフラッシオーバ時間 $10 \mu \mathrm{s} \sim$ 数 $\mathrm{ms}$ までの広範围にわたって適合している。 $k$ の値 は印加電泎の上䒜とともに減少する。一例として $3 \%$ 正極性の場合印加電生各 $5,10,15 \mathrm{kV}$ 亿齐してそれ
ぞれ $k=2.7 ， 0.27 ， 0.13$ となる。ここで $k$ の政泌 な物理的意味は吟味できないが，(3)式の右辺老 $k$ 倍 することは同式の $\left(E_{100}-E_{n}\right)$ 在 $k\left(E_{100}-E_{n}\right)$ 亿简 換するものでする。 $E_{n}$ は空温付対する忮膜のエネル

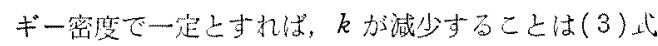
で $E_{100}$ が減少吉るととと同義である。つまり印加是 圧が高くなると，アーク连展機满方熱的なすの加らし だいに㷛電的なもの一推䔟するのに対応して, 皮膜工 ネルギー密度が $100^{\circ} \mathrm{C}$ 相当にならなくても進展可能上 なることを物語るかに見受吋られる。しかし，フラッ

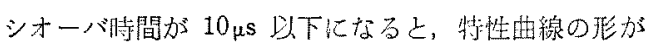
変わり，熱的見地加尊いた $(2)$ 式に適合しなくなる

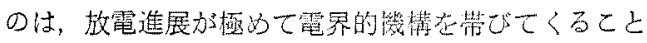
を示すむの上解される。

〈5・3〉 アーク進展に対する臨界温度印加電生 加低い場合には，アークの進展は通路皮滕温度 $100^{\circ} \mathrm{C}$ となる点の動きとして，熱的化扱ってよいもの上思 う。四加電压が高くなった場合にも同様に皮膜温度上 昇の伝搬に放電の進屡在刘応させ上う上す机ば，皮膜 温度は沸点でなくこれよりも低い温垭の伍搬考えな

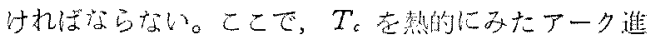
展のための臨界温度上呼かしとすると, 臨界温度は印

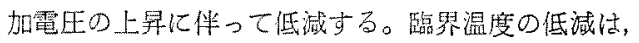
放電の准展㙨满が純挑に效的なるのから, 電界の效果 を帯びた愁電的なものへの移行走示式指標の一つ之見 ることがでさよう。

さて, 第4 図の $V-t$ 特性在参照しつつ印加電目, 塩水澱等の变化によって臨界温度がいか心资化してゅ っくかを調ぺるととする。皮膜温度上显の計算にす たては(1)式の場合上同様にスポット直前で電流線が 通路幅一ぱいに边加った点化著目し，かつこの点加ら 対極灾での残余通路任全印加電印が加加る屯の上して

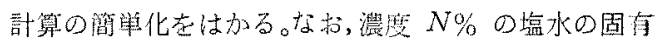

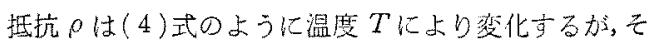
の効果は step-by-step 法で考慮に加えることよする。

$$
\rho=(3 / N) \times 28.9\left(1-7.58 \times 10^{-3} T\right)(\Omega-\mathrm{cm})
$$

前節に述べなよう，印加䉓圧が一定ですってもつ

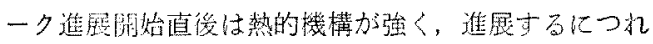

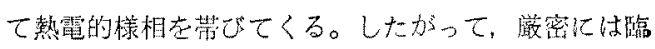
界温度はアーク伸唇上とも低下寸るはずでするが，

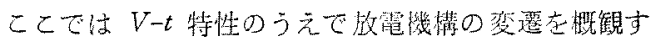

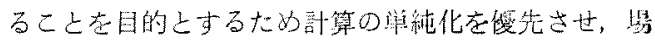
所のいかんにかかわら才゙佫一的な臨界温度という意味

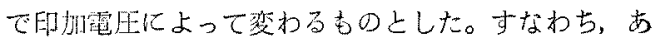




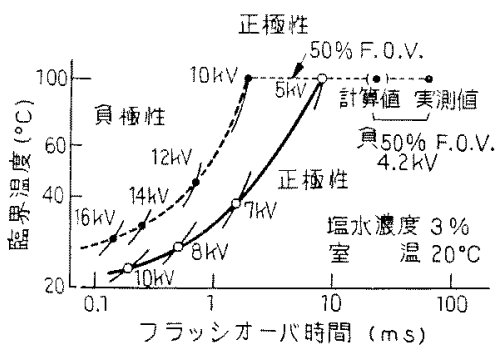

第 7 図 放電進展の臨界温度

Fig. 7. Critical temperature of leakage path.

る盯加霹压の下での臨界温度の想定值を $T_{c}^{\prime}$ とし, 皮膜温度が $T_{c}^{\prime}$ 亿達した点までアークが伸びると考 え，アークが対極に達するまでの所裂㭙間 $t_{f}{ }^{\prime}$ 求 める。し放し，初如に想定する $T_{c^{\prime}}^{\prime}$ の傎の高低に応じ て $t_{f^{\prime}}$ は長短変化する。そこで逆に， $t_{f^{\prime}}$ が实測のフ フラッシオーバ時間上一致するような值 $T_{c}$ 志探し, て机を当該印加電任に対する臨界温度上する。

臨界温度想定䛧 $T_{c}{ }^{\prime}$ 变化させ，二机に刘灾する $\boldsymbol{t}_{\boldsymbol{s}}{ }^{\prime}$ を電子計算機在用い step-by-step 法で計算した結 身在图示したものの一例が第 7 図である。实測のフラ ッシオーバ時間と一致する点老図中 ○・四で示して ある。こ机号の点儿対応する $T^{\prime}$ 加当該条件下での

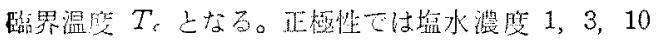
\%ともフラッシオーバ笔臣の上さのみ， $100^{\circ} \mathrm{C}$ の臨界

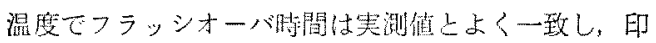
加電圧の上昇に対しては直ちに $T$ 。在低減させ极ばな らない。しかし負極性では塩水溾度 1 10\%の各場合 とも50\%フラッシオーバ值上その約 2 倍の電王の間 の应い区間にわたって臨界温度として $100^{\circ} \mathrm{C}$ 㠻採用し なけ执はらなない結果となっている。融算にさいし，供

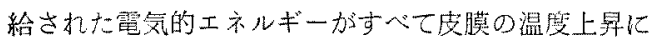
寄与するとして熱損失を然視した大つかかみな考察とは

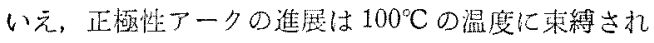
ることが少く，真アークの伸びは $100^{\circ} \mathrm{C}$ まての温度上 景老必要上する電压範囲があり，V-t特性上で熱的上 胃られる分野か広い上解瀵され，正・負極性に上る特 性差の一端を示すもののようである。さらに，印加電 压老增大するにつ机臨界温度倠下して常湿（伎膜の 初期温度て $20^{\circ} \mathrm{C}$ )に近つくことは正・負いず机の極性 でも同様である。特にフラッシオー八時間が $10 \mu \mathrm{s}$ 以

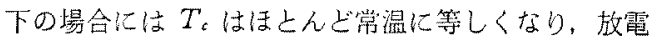
進展には熱的效果上りも電界的効果加優勢よなること
を示しているものと解釈される。

\section{6. むすび}

污損がいし類のフラッシオーバ現象に捄いて最も重 姴な意味をもつ，污損沿面化発生・進展する局部丁 一クの本性老理解する一つの方法として，放電の样柖

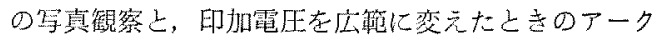
進展の時間恃性上から，污損沿面放電の准展機構の推 移を調べてきた。その結果，金属や炭素電極間に生ず るアーク放電化対しいわ机る霆界放出や熱電子放出の

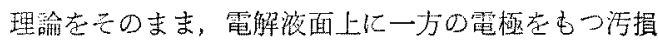
沿面アークに適用して，放電現象の全てを説明するこ とは不可能上思われることを指摘した。污損沿面放電 の機構は印加電王の低・高に徉がって通路の熱的現象 を著しく伴う屯のから，しだいに，電界現象的なもの

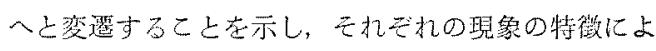
$っ \tau$, 熱的, 熱電的, 電界的進展機構々三つに分類し て放電特性をはすくすること老提案した次第である。

次に局部アーク進展特性在通路の温度上昇汇関連つ けて教察を行ない, 乥の結果, 目極性アークではアー

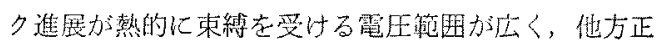
極性ではえの籍围が狭いことが和かった。しかしいず れの極性に执いても，印加電圧をより高くするとアー ク進展特性は熱的なもの加らしだいに電界的椂相を带 ひてくることを示喓している。

熱的分野では通路变形が著しいたか，アーク進展特 性老詏筧により求めるこよはできないか，他の分野で は算定可能の見通しで，元のためには現象の熱的要因 之電界的要因の定昷的な測定を行なうことが必要で今 㣪の研究課題としたい。

耛かりに，本研究の実龭・棓算の面加ら協力いただ いた，尾崎忠義，小柳塔二，安藤徤一，下川原直明の 各氏に謝意表する。

(昭和 49 年 2 月 4 日受付, 同 49 年 8 月 5 日再受付)

\section{文献}

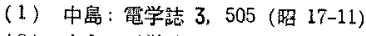

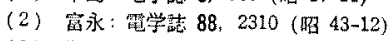

(3) 濑田, 化: 筧咞レポート148(昭 39)

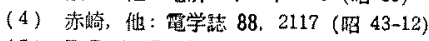

(5) F.D. A. Boylett, et al. Proc. Roy. Soc. 324, A, 1559 (1971)

(6) J.K. Bragg, et al. : J. Appl. Phys. 25, 3, 382 (1954) 